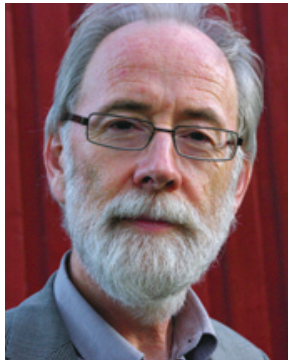

Arild Stubhaug

Forfatter

Foto: privat

\title{
Haldningar er ein seig materie
}

\section{Om forventningar til fastlegen \\ og helsevesenets oppbygging}

| 1950-åra blei legane nærmast sett på som smågudar, og som pasient kunne ein kome i tvil om kven som hadde eigarskap til kroppen. Legane syntest ikkje å vere i tvil. Med makt til å ordinere livreddande medisin i ein befolkning som framleis mintest tida før antibiotika, låg alt til rette for å operere som ein slags kroppens presteskap. På den tida var det ein usagt regel at pasienten skulle stille blank til konsultasjonen, ikkje røpe eventuell innsikt i medisinske forhold. Ein god pasient skulle vere lydig og tålmodig og ikkje stille spørsmål ved behandlinga.

| 1960-åra tenkte helseministeren høgt i same retning: Det var viktig at pasienten ikkje bekymra seg, for mykje kunnskap om sjukdom kunne virke negativt. Det var oftast ekspertar som uttalte seg og bestemte i kva retning folkeopplysninga skulle gå. Men utviklinga gjekk såpass sakte at det framleis var råd både å legge strategiar og følgje dei opp.

Men så blei det fart i sakene: Kunnskap og makt var ikkje lenger på same naturlege måte knytt saman. Ordtaket om at kunnskap er makt, må stamme frå den gongen utdanning var for dei få som alt hadde makt. Seinare gjekk det inflasjon i det heile. Makta gjekk under jorda, samtidig som folkestyret for alvor skaut fart. Synet på legar og kroppar kom i rivande utvikling. På eit eller anna tidspunkt fekk pasienten tilbake eigarskapet til kroppen sin. Inga høgtideleg overrekking, snarare ei litt diffus ansvarsfråskriving. Av økono- miske grunnar måtte liggedøgna på sjukehusa ned, rekonvalesens var ut, antibiotika kur mot det meste, og legane blei litt etter litt reduserte til å vere ein slags reseptskribentar. Legegjerninga syntest å likne eit serviceyrke, og den einskilde lege kunne sikkert kjenne seg skvisa mellom borken og veden: Enten på helsepolitikarane si side, eller på pasientane si side. Men alltid hoggestabbe for sparekniv og pasientfrustrasjon.

Det blei ikkje enklare ved at pasientrettar og klageinstansar gav inntrykk av at helse var ei vare ein hadde krav på. Sjølv om klagene sjeldan fører fram, har instansane ein dempande og kamuflerande effekt: Helse er ein rett, helse er din rett! Og i siste instans: Helsa di er ditt ansvar.

Sjølvsagt er mi helse mitt ansvar, problemet er den glidande overgangen frå det motsette. Problemet er haldningane. For haldningar er som regel inga bevisst sak, ikkje noko som med jamne mellomrom blir tatt opp til revisjon. Haldningar er ein seig, ofte nedarva og miljøbestemt materie, eit resultat av den folkeopplysninga som gjekk føre seg generasjonar tidligare. Slik synest ikkje den einskilde si haldning til helse, kropp og legar å vere à jour med dagens situasjon.

Vi går til legen med forventning om å bli tatt hand om, og sjølv om det på ingen måte blir sagt, kan ein tru at det no er legen som tar kontrollen. I femminuttarskonsultasjonane kan det vere stor forskjell på kva legen høyrer og det ein som pasient trur ein har formidla. Når legen seier «vi tar nokre prøver, om det er noko, høyrer du frå oss», kjennest det som ei bør blir løfta av skuldrene. Det er først når vi ikkje høy- rer noko, men framleis er like dårleg, at uroa melder seg. Dersom prøvene ikkje viste noko, må alt vere «normalt». Kanskje plagene er innbilte, psykiske, stressrelaterte, sjølvpåførte?

Den moderne legen med hundrevis av pasientar har sjølvsagt ikkje tid til å lese prøvesvar og gruble over den einskilde pasienten. Berre dersom det kjem positive svar på prøvene, slår automatikken inn, pasienten blir kontakta og resept skriven, eller nye prøver ordinert. Legen seier det sjeldan høgt, men reknar med at pasienten sjølv tar ansvar og ber om ny time dersom plagene held fram. Men pasienten gjer ikkje nødvendigvis det. Fortidige haldningar til kropp, legar og helse gjer seg gjeldande: Vi troppa opp og viste tillit, ikkje noko gale blei påvist, og lysten til å bli avvist endå ein gong kan vere heller liten. Betre å vente, ta ansvar for eiga helse og halde ut.

Helsevesenet er snekra for å gi lik behandling til alle, men om ein har ein sjeldan sjukdom, må ein i praksis vere kunnskapsrik for å få hjelp, i tillegg pågåande og immun for alle dei subtile, men effektive sperrene som finst i systemet. Lykkast ein i å forsere desse, kjem ein ikkje utan vidare nærmare ein diagnose eller kur. Dyre undersøkingar kan resultere i det same som hos fastlegen: Ingenting unormalt funne, ikkje eit ord om vegen vidare. Tilbake til start.

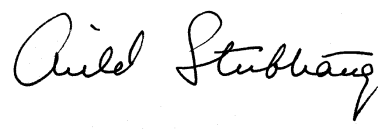

